\title{
Global Drivers for ESG Performance: The Body of Knowledge
}

\author{
Dan Daugaard ${ }^{1,2, *(1)}$ and Ashley Ding ${ }^{1(1)}$ \\ 1 Centre for Corporate Sustainability and Environmental Finance, Macquarie University, \\ Sydney 2000, Australia; ashley.ding@mq.edu.au \\ 2 Tasmanian School of Business and Economics, University of Tasmania, Hobart 7000, Australia \\ * Correspondence: dan.daugaard@utas.edu.au
}

check for

updates

Citation: Daugaard, D.; Ding, A.

Global Drivers for ESG Performance:

The Body of Knowledge.

Sustainability 2022, 14, 2322. https://

doi.org/10.3390/su14042322

Academic Editor: Giuliana Birindelli

Received: 19 January 2022

Accepted: 12 February 2022

Published: 18 February 2022

Publisher's Note: MDPI stays neutral with regard to jurisdictional claims in published maps and institutional affiliations.

Copyright: (C) 2022 by the authors. Licensee MDPI, Basel, Switzerland. This article is an open access article distributed under the terms and conditions of the Creative Commons Attribution (CC BY) license (https:// creativecommons.org/licenses/by/ $4.0 /)$.

\begin{abstract}
Progress on Environmental, Social and Governance (ESG) issues is vastly different depending where in the world you look. However, the literature on what drives ESG performance is highly fragmented and current theories fail to offer useful insights into the disparity in ESG performance. Hence, this study draws upon an accumulated body of knowledge of ESG-related literature and explores the major drivers of ESG performance. By applying a scientific and replicable methodology of systematic literature review, this article reveals the fundamental debate underpinning ESG responsibility, the breath of pertinent stakeholders, the theories necessary to understand ESG management and the conditions which will best achieve ESG progress. The major themes help inform the most effective choice of mechanisms to improve ESG outcomes. However, there are also significant themes not yet fully developed in the literature. Future research is urgently needed on the impact of economic development, regulatory environment and responsible investing on ESG outcomes. These research trajectories hold important implications for investment management, corporate strategy and government policies affecting global ESG performance.
\end{abstract}

Keywords: environmental, social and governance; systematic literature review; responsible investment

\section{Introduction}

The impacts of climate change that face the international community are global in scope and unprecedented in scale. Holding temperatures at $2^{\circ}$ above pre-industry levels would require a dramatic shift in public and private investments from fossil fuels to more climatefriendly alternatives [1]. It will also necessitate coordinated actions and collaborative efforts from various societal stakeholders to strengthen the global response to climate change. Hence, the transition to a low-carbon and climate-resilient economy represents a "grand challenge" [2] facing humanity. Over the past few years, the growing recognition of this challenge has drawn greater attention to environmental and social risks combined with governance issues and catalysed substantial capital toward sustainable development. To meet the growing demand for this form of responsible finance, Environmental, Social and Governance (ESG) scores are increasingly used as a tool to assess the alignment with transition pathways to sustainability (in general, ESG scores are employed to evaluate individual companies but can also be applied to evaluate countries and regions).

A review of global ESG scores in the Sustainalytics database indicates that countrylevel ESG scores display significant variation across the global landscape. There is wideranging disparity in ESG performance across countries but also for individual countries through time. The differences in ESG performance can potentially reveal drivers for good performance and therefore inform strategies and policies for future improvement. Previous studies have proposed and discussed possible theories to explain ESG outcomes, including agency, stakeholder, signalling/disclosure, institutional, legitimacy and stewardship relevant to the drivers of ESG activities. (Agency theory [3] and stakeholder theory [4] are the two common theories that are used to understand the link between corporate governance and sustainability performance. Agency theory predicts that companies protect investors 
and reduce agency conflicts using control mechanisms, such as the corporate governance structures [3]. Stakeholder theory appears to be the prevailing theory of corporate sustainability as suggested by Freeman [4]. Stakeholders have reciprocal relationships and interactions with a firm in the sense that they contribute to the firm's value creation and their well-being is also affected by the firm's activities. Stakeholder theory thus argues that it is important for companies to establish strong relations with stakeholders to maintain and improve corporate legitimacy [5]. Hence, ESG initiatives become a tool of addressing the requirements of shareholders and stakeholders and providing them with the knowledge to evaluate business practices. For stakeholder theories, ESG performance enhances long-term corporate growth and creates firm value by ensuring lower explicit costs, greater operation efficiency [6], improved corporate reputation [7] and increased competitiveness of the company [8]. Legitimacy and institutional theories are closely related to stakeholder theory in the sense that only those with legitimate claims and institutional identification can be considered stakeholders). While these theories provide a useful lens for understanding ESG drivers, they have a limited focus. The established theories have concentrated on management strategies and governance practices to promote corporate performance improvement and create value for stakeholders. The prevailing theories tend to explain the drivers behind ESG initiatives from the perspective of internal governance, documenting associations or casual relations between characteristics of firm management and ESG activities. As a result, these theories fail to offer useful insights into the disparity in ESG performance at the macro level.

By contrasting the ESG scores in the Sustainalytics database, we have also deduced likely drivers such as political settings, economic wealth, the extent of socially responsible investment (SRI) activities and cultural differences. The number and complexity of this collection of drivers creates the need for a thorough review of the current knowledge on ESG performance. This knowledge will enable the identification of the key levers for change and motivate the development of a future research agenda. The significant variation in the regional ESG scores also suggests that there is limited understanding of ESG issues and the barriers to ESG improvements. A fuller comprehension can motivate more appropriate choices of regulation and other incentivising policies to stimulate a wider pursuit of ESG success.

Given the limited knowledge of how to best manage organisations and their economic, regulatory and cultural settings to effectively achieve positive ESG outcomes, we draw upon an accumulated body of knowledge of ESG literature and explore the major drivers of ESG performance. Reviewing broad fields on major drivers of ESG results is a challenging task because of the idiosyncratic nature and fragmentation of the literature. Therefore, a systematic literature review (SLR) is implemented to synthesise and integrate the findings from existing studies in a scientific manner. Specifically, a well-established bibliographic map methodology is applied to underscore the most influential studies, highlight their connections and review their theoretical underpins and contributions [9]. Unlike other types of literature assessments, this approach allows for an objective assessment of the development of thought on a field of research over time, thus eliminating the possibility of self-selection bias $[10,11]$.

Major sub-groups of the collected articles can be organised along four major themes: (1) government vs. freedom, (2) institutional, organisational and individual levels, (3) stakeholder theory and (4) corporate social responsibility. Although overlapping, these themes deliver individually unique insights into the drivers of ESG success. In addition, we identify themes in their early stages of development, which adds significant scope to expand the theoretical and empirical research on what drives ESG outcomes. These emergent themes include ESG drivers attributable to economic development, regulatory environment and socially responsible investing. As nascent research trajectories, these themes will enhance the ability of investment management, corporate strategy and government policies to bring about positive ESG outcomes. This study also outlines emerging research trends and 
pathways for future research and identifies opportunities to advance our knowledge of ESG drivers.

The practical implications of this research are wide ranging and essential. Society demands remedies to the world's ESG issues. Governments are under considerable pressure to provide leadership and implement policies to solve these problems. Understanding what causes ESG performance will therefore inform their choice of policies and regulations to facilitate positive ESG outcomes. Company management is also under pressure from society to deliver ESG improvements, particularly in relation to the problems they create. ESG ratings act as useful quality and performance indicators for the outcomes achieved by government and companies. They can therefore indicate risks and opportunities faced by businesses and the broader economy. Finally, this information is also important for investment managers. In addition to managing portfolio risk, understanding ESG drivers can also reveal opportunities for investors to have impact on ESG outcomes. There is great potential for all major actors to bring about positive ESG change. Whether government, management or investors, knowledge of the ESG drivers will instruct action.

\section{Geographic Heat Map of ESG Performance}

To identify the major drivers of ESG performance, we first explore the Sustainalytics ESG database to map and comprehend sustainability patterns across the globe. In general, ESG scores refer to the three central pillars that reflect the commitment, performance and effectiveness of a company in the context of sustainability. Within each pillar, companies are evaluated based on a wide spectrum of issues that are not part of the traditional financial analysis but may remain value relevant to investor decision making. This might include management of carbon emissions, use of renewable energy resources, workplace policies regarding diversity, political stance on human right issues and executive compensation guidelines. Companies that score well on ESG metrics are considered to better anticipate and manage future non-financial risks and opportunities.

Exploring ESG performance across the globe shows "geographic matters" [12] that ESG scores vary greatly from region to region and are changing through time. Figure 1 compares Sustainalytics ESG Risk Rating [13] between 2009 and 2018 across different geographical areas. These scores are collated from each country's individual company's approach to ESG policies, ESG reporting transparency and responses to ESG events. Overall, the globe is on a positive ESG trajectory. The number of companies coming under scrutiny via ESG rating is increasing. In addition to greater coverage, the data show aggregate improvements over the years.

However, a different story emerges at a more regular level. There is wide disparity: eastern Europe lags western Europe and there are disperse hot spots (e.g., Argentinian and Egyptian environmental scores) and success spots (e.g., South African and Brazilian social scores) scattered across the globe. Further, progress is not uniform-some countries are even going backwards (e.g., Brazilian and Mexican governance scores). This continuing disarray in performance will hamper global success in meeting social and environmental challenges. "Only a coordinated global effort, with participation from public, private, and nongovernmental organizations, can achieve genuine systemic change" [14].

The contrasting performance in Figure 1 also provides some insights into what drives ESG scores. The success of eastern Europe (compared to western Europe) aligns with relative wealth and democratic political settings. These conditions enable representation of broad community concerns with the resources necessary to reflect those concerns. France illustrates the interplay between regulation and the role of institutional investors. French investors must explain how they incorporate ESG factors and the state's energy transition strategy into their investment strategies. This has led to ESG integration by major French institutional investors [15]. Brazil had a reasonably high corporate governance score early on due to strong laws and regulations [16]. However, the governance score fell following the "Lava Jato" corruption scandal, resulting in a strong public backlash and heightened political instability. Despite the overall scores for the Middle East being dragged down by 
the environmental impact of its oil industry, the social scores for this region are reasonably high. This can be attributed to good societal stewardship promoted under Shariah law and Islamic finance.

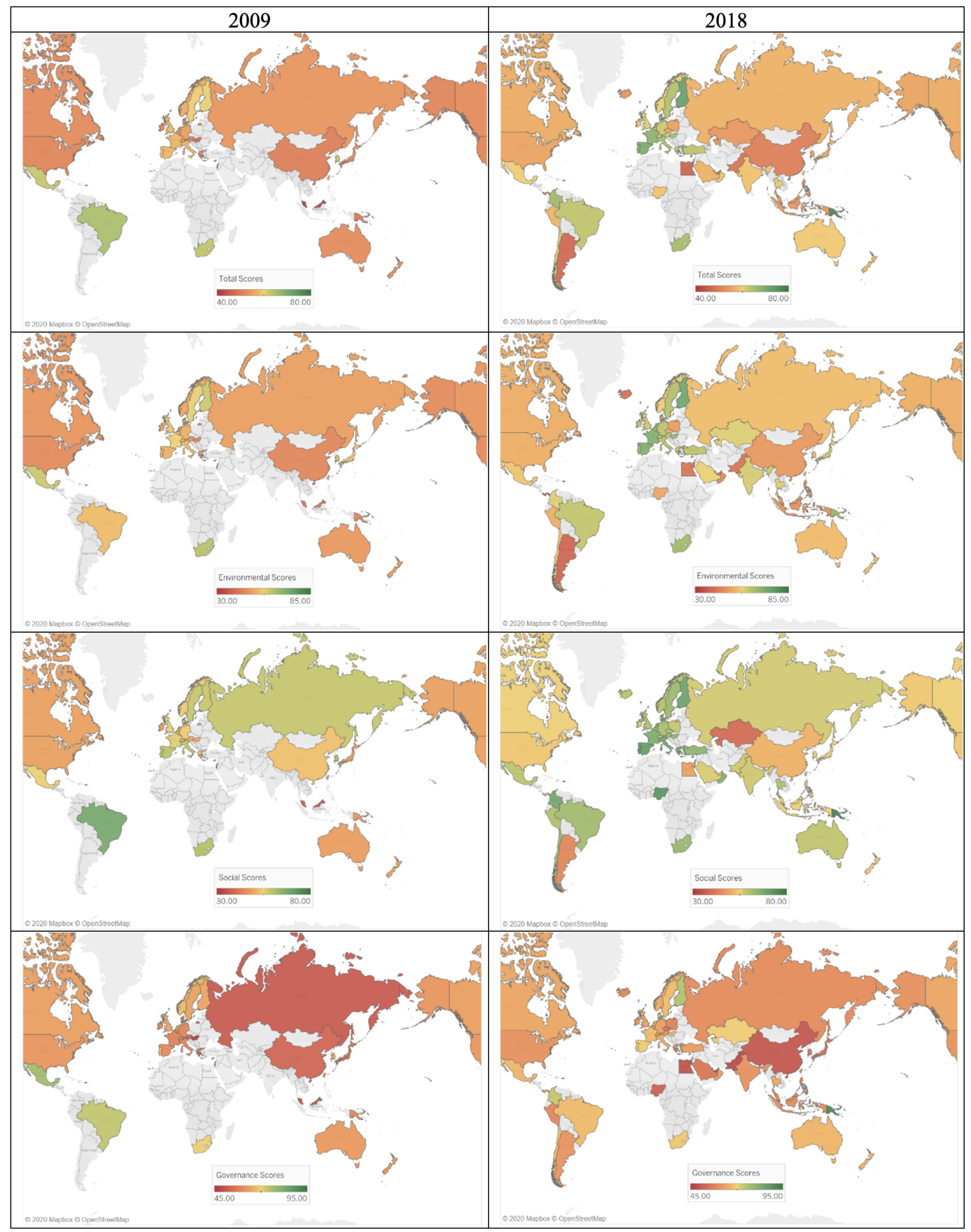

Figure 1. Geographic heat map of ESG performance. These heat maps show the average firm-level ESG scores across countries in 2009 and 2018.

In sum, surveying these differing scores suggests some characteristics that influence ESG performance may include economic and social development, political and regulatory environment and a socially responsible orientation of investors. That is, countries where political systems contain a high degree of democratic representation appear to have the necessary regulation and societal pressure to coerce companies into performing responsibly. In contrast, the relative economic wealth of countries has a mixed effect. While wealth appears to support environmental performance and correlates highly with corporate governance, the impact appears to be negative for social scores. 


\section{Literature Gap}

The literature on what causes ESG performance is highly fragmented. There are many individual research contributions revealing ESG performance is influenced by a variety of aspects. For example, ESG outcomes are influenced by firm size [17], auditing [18], strategy choices [19], board composition [20], stock exchange innovation [21], investors [22,23] and whether the company belongs to an industry which is more sensitive to ESG issues [24]. However, the collection of findings is disorganised and does not easily lead to coherent insights on how to achieve better ESG results.

Given ESG ratings frequently map CSR issues, it is appropriate to extend the preliminary search to explicitly include CSR. This literature is also fragmented. For example, responsible outcomes can be attributable to ethical leadership [25], economics conditions [26], media coverage [27] and the professionalisation of ESG experts [28]. Despite the impressively wide range of drivers, the most dominant theme is about how corporate management and strategy drives CSR [29-33]. In relation to CSR, there is some evidence of synthesis. For example, Vashchenko [34] documented pressure on CSR decision making from a number of external factors (such as economic climate, competitors' CSR policies, investors' CSR concerns, business education and scientific publications, national and local government recommendations and regulations, international CSR guide-lines). Similarly, in relation to CSR disclosure, Ali [35] find the drivers include political, social and cultural factors. However, this literature is incomplete and needs to be tied more closely to ESG outcomes.

The fragmented nature of the literature means it is difficult to attain conclusive and focused knowledge about what drives ESG performance. As a result, it creates challenges for devising coherent recommendations for corporate strategy, government regulation and investment choices. This article therefore contributes to the literature by carrying out a systematically designed literature review and organises the most influential writings into coherent themes. The thematic organisation provides a structured understanding of the important drives for ESG performance. The process of organising the literature also enables the under-developed themes to be identified and a future research agenda to be structured.

\section{Research Methodology: Mapping Literature on ESG Drivers}

Identifying the actual drivers for ESG performance is difficult. There is a wide range of ESG scores across the globe and there are many potential driving forces. A systematic literature review (SLR) is an ideal tool to collate and organise the potential drivers. An SLR establishes a disciplined and scientific approach to making sense of the intellectual analysis which has been applied to this issue. It therefore provides a balanced and unbiased understanding of the field. This enables a confident identification of the drivers to explain the ESG patterns observed globally and through time. Where the literature does not align with the observed patterns, the SLR established a clear agenda for future research.

A detailed approach is necessary to ensure the SLR is replicable with robust and defensible results. The SLR methodology applied here follows Linnenluecke [36]. Initially, key search words are selected to capture the concept of this study. Then, an article search is conducted using a comprehensive database (i.e., Web of Science). The harvest of articles is cleaned by triangulating the views of a team of research academics. The major citations across this collection are analysed to identify the key themes. Finally, the themes are critically reviewed and applied to the context of this study.

A visual presentation provides an important overview of the way the major themes across the published literature interrelate. At the heart of the SLR process applied here is a graph of the major citations using HistCite ${ }^{\circledR}[37,38]$. This graph maps the timing, significance and interconnection of the published collection. The graph therefore highlights the most significant themes to then be considered in light of the current study. In the current case, these themes include government vs. freedom, institutional, organisational and individual levels, stakeholder theory and corporate social responsibility. 


\subsection{Key Words and Concepts}

The motivation for this literature search is to understand the underlying socioeconomic, market and SRI factors driving ESG performance. This motivation directs the choice of key words to be employed in the search. The key words therefore reflect the diverse way in which the ESG measurements are encountered and the four major categories of drives (see Figure 2).

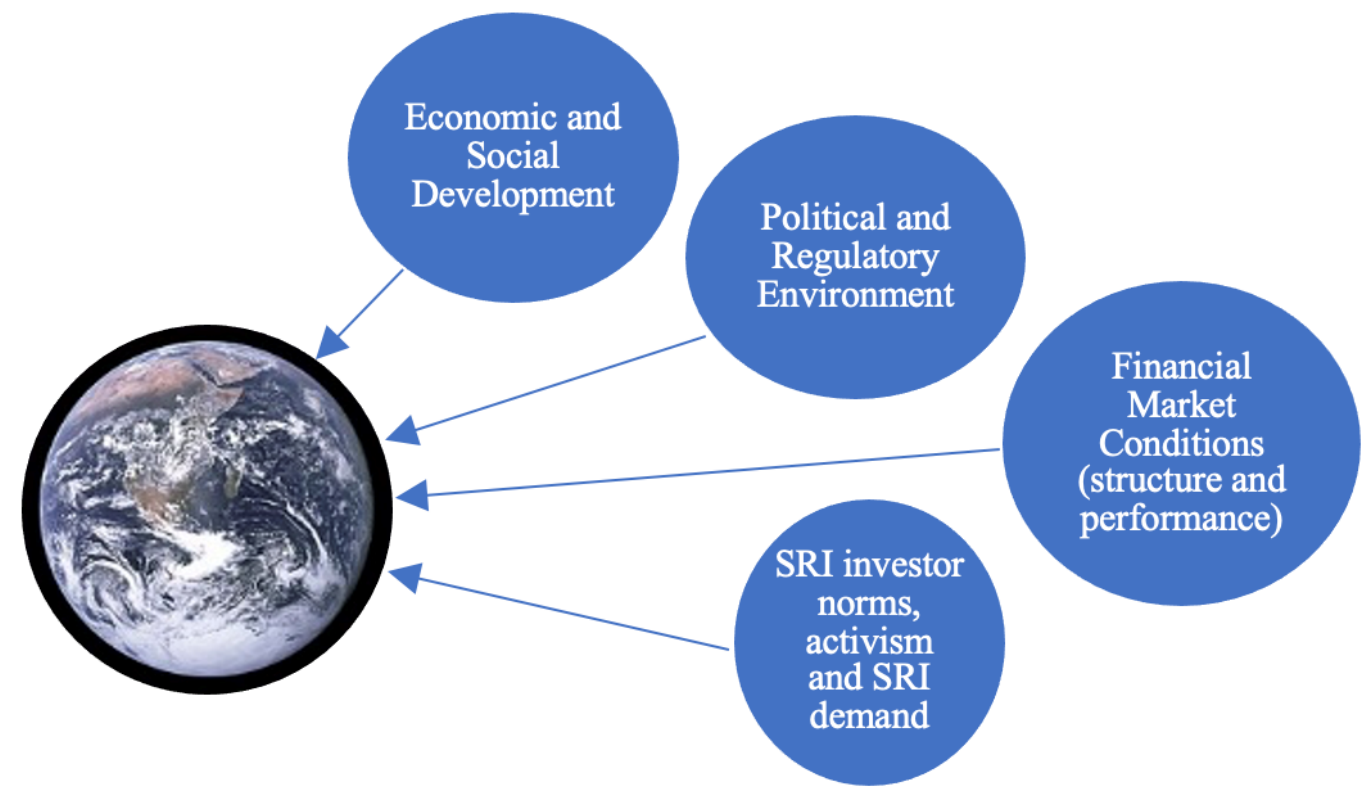

Figure 2. Categories of ESG performance drivers. This figure presents the four major categories of activities, attributes and circumstances which drive global ESG performance.

The terms for ESG include relevant long forms, acronyms and pseudonyms (see Table 1). CSR and related terms were also included because they share a similar concept with ESG but promote sustainable practices from a different aspect. CSR marks the starting point for businesses to take ownership of their impact on society. It generally refers to a corporate vernacular used to describe the willingness of a company to address major societal concerns. Nowadays, CSR merely resembles a marketing or public relations exercise for many companies. The growth of ESG is rooted in CSR; however, ESG assesses businesses through the lens of their sustainable initiatives and societal impacts. ESG criteria make the commitment and efforts of businesses become measurable. Hence, ESG scores and ratings are often incorporated as part of investment analysis or portfolio construction. The other validation for including CSR terms is because these terms were frequently specified as key words in the articles from a preliminary scan of ESG and SRI literature.

The selection of literature is driven by this article's focus on what drives ESG performance. Therefore, an important distinction was made in relation to the causational direction of ESG metrics and profitability. Articles which analysed how ESG, SRI and CSR cause performance were excluded unless they explicitly addressed the reverse pathway, i.e., how profitability drives ESG (often referred to as the "slack resources" concept). Further, the focus on investable companies means that household and community focused articles were also excluded. SDG terms were included because they overlap with ESG issues. The United Nations developed and promoted the SDG's to potentially impact all walks of life. Although wider in scope, the issues of what promotes SDG performance is akin to those which impact ESG performance. They can therefore be thought of as the intergovernmental equivalent to ESG paradigms. 
Table 1. Key word concepts.

\begin{tabular}{|c|c|}
\hline Concept & Key Words \\
\hline ESG context & (ESG OR “E, S and G”) AND (issue\$ OR rating\$ OR analysis) \\
\hline ESG pseudonyms & $\begin{array}{l}\text { (ethic* OR responsib*) AND (invest* OR financ*) AND (issue\$ OR rating\$ } \\
\text { OR analysis) }\end{array}$ \\
\hline Environmental, Social and Governance & $\begin{array}{l}\text { (environment* OR ecology* OR eco OR sustainab* OR green) AND social } \\
\text { AND govern* }\end{array}$ \\
\hline CSR & CSR AND (issue\$ OR rating\$ OR analysis) \\
\hline Corporate social responsibility & $\begin{array}{l}\text { “Corporate social" AND (responsibility OR performance) AND (issue\$ OR } \\
\text { rating } \$ \text { OR analysis) }\end{array}$ \\
\hline SDG & (SDG) AND (issue $\$$ OR rating $\$$ OR analysis) \\
\hline Sustainable Development Goals & (“Sustainable Development Goals") AND (issue\$ OR rating \$ OR analysis) \\
\hline \multicolumn{2}{|l|}{ Categories of Drivers } \\
\hline \multirow[t]{2}{*}{ Economic and Social Development } & economic* AND (develop* OR growth) \\
\hline & (social* OR societ*) AND (develop* OR benefit OR growth) \\
\hline Political and Regulatory Environment & (Politic* OR Regulat*) AND Environment\$ \\
\hline $\begin{array}{l}\text { Financial Market Conditions (structure } \\
\text { and performance) }\end{array}$ & $\begin{array}{l}\text { (Financial AND Market\$ ) NEAR/10 (structure\$ OR micro* OR setting\$ OR } \\
\text { return\$ OR risk\$ OR perform }{ }^{*} \text { ) }\end{array}$ \\
\hline SRI & $\begin{array}{l}\text { SRI OR (social OR socially) NEAR/3 (responsi* OR aware) NEAR/3 (invest- } \\
\text { ing OR investment\$) }\end{array}$ \\
\hline Pseudonyms for SRI & $\begin{array}{l}\text { (sustainab* OR ethic* OR responsible OR norm\$ OR “low carbon" OR “car- } \\
\text { bon neutral" OR ((ESG OR SRI) AND integrat*)) AND (investing OR invest- } \\
\text { ment\$ OR fund\$ OR screen*) }\end{array}$ \\
\hline $\begin{array}{l}\text { OR and NEAI } \\
\text { to find record }\end{array}$ & $\begin{array}{l}\text { the key words used to search the Web of Science database. The asterisk }\left(^{*}\right) \text { represents any group } \\
\text { luding no character. The dollar sign (\$) represents zero or one character. Search operators AND, } \\
\text { re used to combine terms in order to broaden or narrow retrieval. In particular, NEAR/ } x \text { is used } \\
\text { there the terms joined by the operator are within a specific number of words of each other. }\end{array}$ \\
\hline
\end{tabular}

The drivers for ESG outcomes can be thought of along four categories. First, economic and social development potential establish an environment in which the critical issues affecting people can be openly discussed and promoted. Closely related to this first category is the political and regulatory environment. While it is key that critical societal issues be considered, it often requires the influence or action of regulatory authorities to implement the desired policies. Financial market conditions can represent an alternative channel to facilitate the implementation of pro-societal activity, especially if there is a profitable motivation associated with the activities. Finally, there is the category of specialist investment activity targeting responsible and sustainable impact, SRI.

The range of terms which capture articles addressing SRI is wide. This is partly due to way the generically accepted terms evolved through time [39]. For example, the term "ethical" was a broadly acceptable description of this form of investing. However, "ethical" was subsequently replaced by "socially responsible investing" (SRI). More recently, the relevance of the term "social" was queried and frequently replaced with "sustainable" or removed completely to leave the term "responsible investing" (RI). The wide range of terms relevant to this form of investing has also been attributed to the competitive position of investment managers differentiating their products [40].

\subsection{Search Results and Data Cleaning}

The original search for articles on what drives ESG performance returned 266 articles. These articles were reviewed by reference to their titles, key words, publishing journal, 
abstracts and, in the cases where further details were required to distinguish their relevance, the full text of the article. Two researchers carried out this manual review to effectively triangulate the selection. Where the status of an article was not initially agreed, the researchers reviewed and discussed the selection until agreement was achieved. This review reduced the collection by 97 articles. HistCite was then employed to map citation patterns between the identified articles as well as to references not yet in the collection. This enabled the identification of another 35 articles on ESG drivers which had significant influence. These articles were potentially missed in the original search because they were not published in journals listed on WoS or their abstracts did not contain the key words employed in the search.

The analysis of citations to external references also identified four influential items published in this topic area: an item published in The New York Times titled "A Friedman doctrine: The social responsibility of business is to increase its profits" [41] and three books titled Social Responsibility of the Businessman [42], Capitalism and Freedom [43] and Strategic Management: A Stakeholder Approach [4]. Each of these items contained ground-breaking proposals on how to think about ESG outcomes in the context of business. With these additions, there are 208 items in the collection.

Figure 3 is generated by HistCite to highlight the most influential $10 \%$ of items clustered on the basis of citations (the items are listed in Table 2). Each item is represented by a circle. The size of the circles indicate the number of times the item is cited throughout the collection (e.g., the work by Carroll [29] has been cited 29 times in the collection). The items are plotted according to time, i.e., earlier publications are located at the top of the graph and recent articles at the bottom. Lines between the 21 items identify their citations to each other.

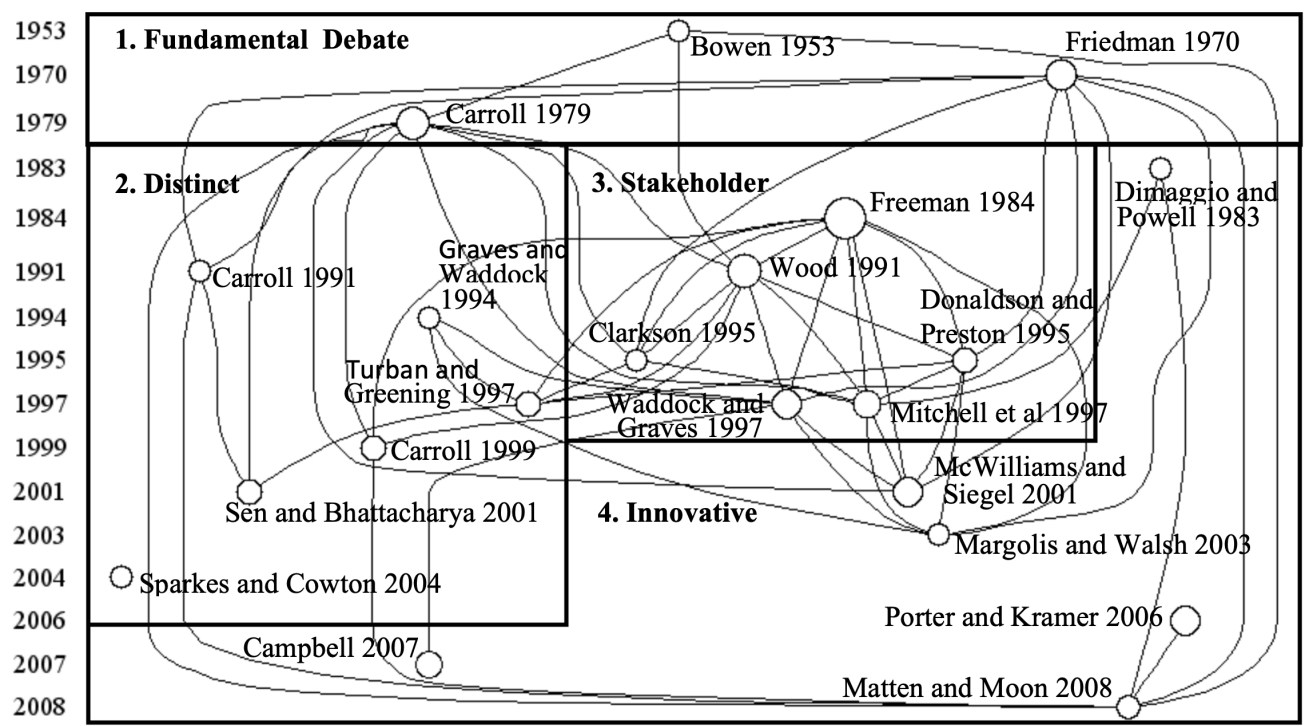

Figure 3. Knowledge citation graph. This figure is generated by HistCite to highlight the most influential $10 \%$ of items clustered on the basis of citations (the items are listed in Table 2). Each item is represented by a circle. The size of the circles indicates the number of times the item is cited throughout the collection (e.g., the work by Carroll [29] has been cited 29 times in the collection). The items are plotted according to time, i.e., earlier publications are located at the top of the graph and recent articles at the bottom. Lines between the 21 items identify their citations to each other. 
Table 2. References in citation graph.

\begin{tabular}{|c|c|c|c|}
\hline Collection \# & Reference & LCS & GCS \\
\hline 1 & Bowen [42] "Social responsibility of the businessman" & 13 & 379 \\
\hline 3 & $\begin{array}{l}\text { Friedman [41] "The social responsibility of business is to increase } \\
\text { its profits" }\end{array}$ & 25 & 3140 \\
\hline 5 & $\begin{array}{l}\text { Carroll [29] "A three-dimensional conceptual model of corporate } \\
\text { performance" }\end{array}$ & 29 & 3213 \\
\hline 6 & $\begin{array}{l}\text { DiMaggio [28] "The iron cage revisited: Institutional isomorphism } \\
\text { and collective rationality in organizational fields" }\end{array}$ & 13 & 51 \\
\hline 7 & Freeman [4] "Strategic Management: A Stakeholder Approach" & 45 & 1615 \\
\hline 9 & $\begin{array}{l}\text { Carroll [30] "The pyramid of corporate social responsibility: To- } \\
\text { ward the moral management of organizational stakeholders" }\end{array}$ & 14 & 2210 \\
\hline 11 & Wood [44] "Corporate social performance revisited" & 31 & 1754 \\
\hline 15 & $\begin{array}{l}\text { Graves [45] "Institutional owners and corporate } \\
\text { social performance" }\end{array}$ & 13 & 466 \\
\hline 17 & $\begin{array}{l}\text { Donaldson [46] "The stakeholder theory of the corporation: Con- } \\
\text { cepts, evidence, and implications" }\end{array}$ & 18 & 3823 \\
\hline 18 & $\begin{array}{l}\text { Clarkson [47] "A stakeholder framework for analyzing and evalu- } \\
\text { ating corporate social performance" }\end{array}$ & 13 & 2429 \\
\hline 20 & $\begin{array}{l}\text { Waddock [33] "The corporate social performance-financial per- } \\
\text { formance link" }\end{array}$ & 23 & $?$ \\
\hline 21 & $\begin{array}{l}\text { Turban [48] "Corporate social performance and organizational } \\
\text { attractiveness to prospective employees" }\end{array}$ & 18 & 1233 \\
\hline 22 & $\begin{array}{l}\text { Mitchell [49] "Toward a theory of stakeholder identification and } \\
\text { salience: Defining the principle of who and what really counts" }\end{array}$ & 21 & 4087 \\
\hline 24 & $\begin{array}{l}\text { Carroll [50] "Corporate social responsibility: Evolution of a defini- } \\
\text { tional construct" }\end{array}$ & 18 & 2136 \\
\hline 29 & $\begin{array}{l}\text { McWilliams [51] "Corporate social responsibility: A theory of the } \\
\text { firm perspective" }\end{array}$ & 22 & 2420 \\
\hline 33 & $\begin{array}{l}\text { Sen [52] "Does doing good always lead to doing better? Consumer } \\
\text { reactions to corporate social responsibility" }\end{array}$ & 17 & 1714 \\
\hline 38 & $\begin{array}{l}\text { Margolis [53] "Misery loves companies: Rethinking social initia- } \\
\text { tives by business" }\end{array}$ & 14 & 2003 \\
\hline 43 & $\begin{array}{l}\text { Sparkes [54] "The maturing of socially responsible investment: A } \\
\text { review of the developing link with corporate social responsibility" }\end{array}$ & 14 & 242 \\
\hline 52 & $\begin{array}{l}\text { Porter [32] "The link between competitive advantage and corpo- } \\
\text { rate social responsibility" }\end{array}$ & 22 & 3184 \\
\hline 55 & $\begin{array}{l}\text { Campbell [26] "Why would corporations behave in socially re- } \\
\text { sponsible ways? An institutional theory of corporate social respon- } \\
\text { sibility" }\end{array}$ & 20 & 1544 \\
\hline 62 & $\begin{array}{l}\text { Matten [55] "'Implicit' and 'explicit' CSR: A conceptual framework } \\
\text { for a comparative understanding of corporate social responsibility" }\end{array}$ & 15 & 1547 \\
\hline
\end{tabular}

This table lists the references displayed in the citation graph. Collection number is the number of the article in the full collection in order of publication date. The reference details show the authors, year of publication and article title. LCS is the local citation score within the collection. GCS is the global citation score in the Web of Science.

\section{Main Features of Literature Collection}

Identifying the specific elements which drive ESG performance is the principle focus of this literature review. This focus informed the selection of key words for the literature. As a result, the bulk of the articles harvested for the collection contain detailed conditions and attributes which affect ESG outcomes. Further articles were added to the collection if 
they received significant citation counts from the original harvest. Many of the additionally added, highly cited articles contain the big ideas, principles, theories and frameworks which motivated subsequent theory development and empirical research. The references that identify specific drivers (e.g., as independent variables in regression models or decisions to make in approaches to strategic management, etc.) draw upon these most cited references for their fundamental underlying theories and premises. Therefore, the citation graph comprises both water shed articles defining major philosophies and theories, as well as detailed papers drilling down into specialized lines of thought. A full picture of what drives ESG performance is therefore achieved through a full review of the complete collection. The following sections therefore treat the big ideas, theories and counter arguments but also draw references to the extended research into specific variables which model ESG drivers. Investment managers, corporate strategists and policy setters will benefit from understanding both the big picture themes as well as the detailed levers to achieve positive ESG results.

There are four major areas of the literature collection. The first area contains the earliest highly cited contributions. They set out the debate which underpins much of the literature and an archetypal model for understanding the issues. The second area demonstrates the potential heterogeneous nature of this body of knowledge. It is a collection of research showing the different perspectives of the distinctly different stakeholders, e.g., employees, customers and institutional investors. The third area emphasises stakeholder theory, including the importance of where the line between stakeholders and the wider community is drawn. Finally, the fourth area provides an overview of the innovative theories and frameworks being developed to understand, monitor and manage business social responsibilities.

\subsection{Fundamental Debate}

The earliest three articles present the defining nature of this collection of literature. These articles clearly state the fundamental debate between social good vs. economic success and illustrate a framework for synthesising social reasonability concerns and responses. Bowen [42] is considered the foundational work of the "academic conception and study of corporate social responsibility" ([56], (p. 607)). Bowen [42] establishes a beachhead for responsible business management and attracts a passionate defence of profitability from Friedman [41]. These two articles capture the tension between profitability and social responsibility which underline many of the specific problems and contexts arising throughout the collection of articles. Carroll (1979) is foundational in a different sense: it establishes an initial model for conceptualising and operationalising responsible performance. This model is a headwater for the impressive streams of models, frameworks and theories developed across the full expanse of this literature.

Bowen [42] was motivated by concerns over the role of "big business" in society following an unprecedented period of growth in size and power of corporations [56]. Bowen [42] is an inspiring analytical perspective on social responsibility. In addition to setting out the debate, he provides a critical perspective on the responsibilities of business and the institutionalisation of this responsibility. Acquier [56] identify seven contributions from Bowen [42] which can reinvigorate researchers and practitioners today:

- Social responsibility systematically spans many dimensions;

- Current misconceptions can be corrected by the historic discourse;

- Social responsibility fits neatly into institutional theory;

- New forms of regulation are superior to direct state interventions;

- Conceptualising how corporations create social welfare;

- Education has the power to transform awareness;

- Socialisation norms and values by embedding managers in social and organisational contexts.

Friedman [41] responds to the call for social responsibility by framing a debate between state control vs. political and economic freedom. He argues that economic freedom 
is necessary for political and individual freedom and therefore promotes laissez faire economics over government intervention (though tariffs, subsidies and regulations). He subsequently sharpens his arguments for the context of a business' social responsibility. By carrying out activities for social good, Friedman argues that a corporate executive is effectively imposing taxes and allocating resources without the oversight normally associated with an elected government. His central theme is that corporate executives should focus on profit performance and leave social responsibilities as an aspect of their personal choices unrelated to their employment. While Edmans [57] argues that Friedman's views are actually more socially enlightened than most believe, the "Friednzan" doctrine is encountered frequently throughout the collection as a negative starting point to provide motivation for progressive responsible research.

Carroll [29] presents a foundational model for understanding and implementing responsible performance. This model has been a significant forebearer of models developed across the literature collection. Carroll's model requires defining social responsibilities, identifying social issues and describing a response philosophy. Defining social responsibilities clarifies what motivates societies' expectations, i.e., economic, legal, ethical or discretionary. Separate to defining responsibilities, we need to identify the current issues relevant to a particular company's industry. Finally, the model articulates a company's philosophy of responsiveness. For example, companies could be reactionary, defensive, accommodating or proactive in responding to social concerns. It is likely that responsiveness drives desired ESG outcomes [58]. Carroll [29] also describes many applications for academic research and business management. The model is also an early exemplar for the frameworks created for CSR reporting and implemented by ESG ratings agencies.

\subsection{Distinct Stakeholders}

These articles prove responsible practices are important to a wide range of stakeholders. The articles demonstrate responsible corporations are attractive to employees [48], customers [52] and institutional investors [45,54]. This broad range of interested actors echoes the CSR definitions presented in Carroll [50]. This author maps the maturing of CSR leading to a range of theories and thematic frameworks. In doing so, he identifies additional important stakeholders: dealers, local communities and the nation. His earlier article (in this section) also emphasises an additional actor-the role of Government in creating legislation and regulators [30].

A thorough review of the conditions which impact CSR is contributed by Campbell [26]. He deduces the conditions which contribute to successful CSR engagement:

- Firms can be successful when they experience strong profitability;

- Industries succeed when they have lower levels of competition;

- Regulated environments can work when the state has the capacity to monitor and act;

- Industries succeed with healthy self-regulation and active stakeholder monitoring;

- The presence of institutionalised norms contributes to success;

- Strong membership of peer associations facilitates success;

- Clear channels of communication and appropriate education underpins success.

This collection of detailed conditions reveals the significant role of coordinated communication and action between the broad range of stakeholders. The only major disappointment with the propositions from Campbell [26] is the limitation of scope. Elements of society are incorporated but only in very close connection to the firm (e.g., employees, customers and media coverage). The following area of literature specifically addresses this issue in terms of contrasting the stakeholders closely associated with the firm in comparison to those which represent the wider community setting.

\subsection{Stakeholder Theory}

Social responsibility, and more widely, social issues management, is presented as a key element of successful management. This broader set of management's objectives means that good managers should be able to achieve both profitability and good ESG 
outcomes [33]. This section of articles focuses on stakeholder theory to examine if and when both objectives can be achieved. The articles include frameworks for operationalisation of societal objectives.

Freeman [4] is the most recognised opponent to Friedman's view of the primacy of profitability. In his book, Freeman "proposed a view of a firm as the convergence of interests and expectations that needed to be considered and integrated into the firm's strategy" ([59], (p. 44)). In particular, Freeman argues that a competitive advantage can be achieved by the firm if it is managed for the benefit of its stakeholders. Jones [60] explains that the core theory is driven by trust. He argues that trust, trustworthiness and cooperation represent a source of significant competitive advantage. Donaldson [46] examine the justifications for stakeholder theory and find the theory satisfies descriptive accuracy and instrumental power but is ultimately justified by its normative validity.

The development of stakeholder theory has emphasised a distinction between stakeholders and broader social issues [47]. Stakeholders can be identified on the basis of three relationship attributes: power, legitimacy and urgency [49]. The importance of the distinction is particularly relevant for shareholders. Hillman [61] empirically demonstrate that shareholder value is enhanced by stakeholder management but is reduced when firms attend to the wider issues of society. While this development is positive for the need to address the concerns of stakeholders beyond shareholders, it still leaves responsibility for addressing society issues outside the remit of companies. This insight appears to apply generally; however, a more granular treatment can draw different conclusions for different contexts.

A framework that recognises different businesses will have different approaches to ESG management is offered by Wood [44]. Firstly, as an institution, a business is expected to earn legitimacy through its responsible use of economic power. Different degrees of economic power will result in actions to earn legitimacy. Secondly, as an organisation, a business is expected to solve social problems relating to its activities. The activities of the business will differ depending upon country and industry footprints. Thirdly, individual managers as moral actors in the firm are expected to make discretionary decisions towards socially responsible outcomes. These moral agents are likely to have different moral standards influenced by culture [40].

\subsection{Innovative Theories}

This area of the literature presents innovative theories which categorise the nature of the forces driving ESG outcomes. The innovations include granular details of the organisation and its operating environment, modelling ideal ESG targets (rather than likely outcomes) and thinking about the drivers as internal and external "coercive forces". These innovations provide new insights into the nature of ESG and how positive change can be successfully achieved.

DiMaggio [28] contribute an "institutional isomorphic" framework to identify the forces which lead to corporate behaviours. Their context was how organisations become similar, but their frame can be extended to the context of how CSR behaviours and ESG results can converge. They describe three mechanisms by which organisations change:

- Coercive isomorphism stems from political influence and the problem of legitimacy. In the context of CSR, this can take the form of political pressure (e.g., via regulation) on businesses to perform as well as when corporations demonstrate they deserve a "social license" to operate;

- Mimetic isomorphism is when organisations exhibit similar responses to uncertainty. When CSR issues pose potential risks for companies, they may adopt standard, accepted methods to mitigate their exposures;

- Normative isomorphism is the mechanism associated with professionalisation. As CSR, ESG and SRI practitioners become recognised as professions, their adoption of certifications, standards and behaviour distribute organisational norms across companies. 
This framework can help pinpoint clusters of countries which should have similar ESG performance. For example, countries with common democratic settings are likely to experience similar levels of political influence and demands for legitimacy. Isomorphic frameworks can also explain the specific factors which cause different CSR performance between countries and the evolution in ESG performance through time [55]. For example, Japan's CSR development has been attributed to increased exposure to global capital markets, adoption of American business techniques and education models and national governance challenges. Russian and Eastern Europe illustrate that stronger civil societies and autonomous market institutions are associated with emerging CSR development. Africa, Asia and Latin America also provide evidence of increased CSR due to the isomorphic pressures from imposing industrial meta-standards on environmental, health and safety and human rights standards. This framework can therefore inform regulations, support and incentives which will enhance ESG outcomes.

Consistent with the conceptual underpinning of the isomorphism frameworks, McWilliams [51] build a model of ideal CSR based on demand and supply forces. Their detailed modelling of corporate operations reveals how firm-specific elements can explain the different degrees of CSR carried out by firms in different industries. They show that a firm's ideal CSR can be influenced by R\&D spending, advertising intensity, product differentiation, dependence on government sales, consumer income, labour market conditions and the life cycle stage of the industry. This modelling therefore provides specific variables relevant for empirical testing across different markets and business types.

There are a range of specific channels for recognising and accepting the concept of social responsibility identified in this area of literature. Nevertheless, isomorphism is a wide enough framework that it can help categorise these diverse channels. Porter [32] (p. 1) explain CSR acceptance "as an inescapable priority for business leaders in every country". They therefore attribute the acceptance as a normative isomorphism.

Campbell [26] continues the theme of identifying the wide range of factors which influence ESG outcomes. They argue "the relationship between basic economic conditions and corporate behaviour is mediated by several institutional conditions: public and private regulation, the presence of nongovernmental and other independent organizations that monitor corporate behaviour, institutionalized norms regarding appropriate corporate behaviour, associative behaviour among corporations themselves, and organized dialogues among corporations and their stakeholders".

A further example of a framework which specifies forces behind change is supplied by Aguinis [62]. They identify conditions under which CSR actions and outcomes change as set out in Figure 4. This application of the framework enables detailed modelling and assessment of the individual conditions of a business. A full spectrum of players is identified (e.g., shareholders, consumers, employees, regulators, standard setters, etc.). The motivations, values and awareness are considered as both predictors of action as well as potential mediators (or moderators) in relation to achieving ESG benefits. The detailed process presents great potential to create specific company, industry and country specific models to identify the most important levers for ESG success.

The previous section of readings emphasised a distinction between stakeholders and broader social issues [47] and the shareholder benefit from managing closely related stakeholders and not the wider issues [61]. This perspective leaves responsibility for addressing society issues outside the remit of companies. It is therefore encouraging that the Innovative Theories section includes models presenting a compelling call for an expanded theory [53]. These authors argue that tension between economic value of the firm and the broader societal objectives should be embraced and leads to a more progressive research agenda. Their principal concern is to effectively apply organisational management to resolve global societal needs. However, they raise the caveat that involving corporations in solving wider society problems "may well make problems worse, or even create new ones". 
Multilevel and Multidisciplinary Model of Corporate Social Responsibility (CSR): Predictors, Outcomes, Mediators, and Moderators

\begin{tabular}{|c|c|c|c|}
\hline $\begin{array}{l}\text { PREDICTORS OF CSR } \\
\text { (REACTIVE AND } \\
\text { PROACTIVE) } \\
\text { - Institutional and } \\
\text { stakeholder (i.e., } \\
\text { shareholders, } \\
\text { consumers, media, } \\
\text { local community } \\
\text { interest groups) } \\
\text { pressure (Inst) } \\
\text { - Regulation, } \\
\text { standards, and } \\
\text { certification demands } \\
\text { (Inst) } \\
\text { - Finm instrumental } \\
\text { and normative } \\
\text { motives (Org) } \\
\text { - Fimm mission and } \\
\text { values (Org) } \\
\text { - Corporate } \\
\text { governance structure } \\
\text { (Org) } \\
\text { - Supervisory } \\
\text { commitment to CSR } \\
\text { (Ind) } \\
\text { Values, needs, and } \\
\text { awareness regarding } \\
\text { CSR (Ind) }\end{array}$ & $\begin{array}{c}\text { CSR } \\
\text { Initiatives }\end{array}$ & \begin{tabular}{l}
\multicolumn{1}{c|}{ MODERATORS OF CSR-OUTCOMES } \\
RELATIONSHIS \\
(PEOPLE, PLACE, PRICE, AND PROFILE) \\
- Stakeholder salience (Inst) \\
- Industry regulation and growth \\
(Inst) \\
- Contact/visibility with public (Inst) \\
- R\&D investment and advertising \\
(Org) \\
- Finances/slack resources (Org) \\
- Firm visibility/contact with public \\
(Org) \\
- Firm size (Org) \\
- Supervisory influences (e.g., \\
commitment to ethics, equity \\
sensitivity) (lnd) \\
- Emnloyee discretion (Ind)
\end{tabular} & $\begin{array}{l}\text { OuTCOMES of CSR } \\
\text { (INTERNAL. AND EXTERNAL) } \\
\text { - Reputation (Inst) } \\
\text { - Consumer loyalty and } \\
\text { positive firm } \\
\text { evaluations (Inst) } \\
\text { - Stakeholder relations } \\
\text { (Inst) } \\
\text { - Customer choice of } \\
\text { company'product (Inst) } \\
\text { - Financial performance } \\
\text { (e.g., return on assets } \\
\text { and equity, } \\
\text { attractiveness to } \\
\text { investors) (Org) } \\
\text { - Fim capabilities (e.g., } \\
\text { operational efficiency, } \\
\text { product quality, } \\
\text { demographic diversity) } \\
\text { (Org) } \\
\text { - Reduced risk (Org) } \\
\text { - Enhanced } \\
\text { organizational } \\
\text { identification, } \\
\text { employec engagement, } \\
\text { organizational } \\
\text { citizenship behavior, } \\
\text { and attractiveness to } \\
\text { potential employees } \\
\text { (Ind) }\end{array}$ \\
\hline
\end{tabular}

Note: Inst = institutional level of analysis; Org = organizational level of analysis; Ind = individual level of analysis.

Figure 4. This figure, obtained from Aguinis [62], serves as a multilevel lens and guiding framework for understanding the vast and diverse body of CSR literature.

\subsection{Underdeveloped Literature Themes}

The majority of themes on what drives ESG focus on management literature and are focused on corporate management and strategy. It is therefore important to further develop the other supporting themes of economic drivers, regulatory impact and the influence of socially responsible investors. Figure 5 shows the smaller citation clusters associated with these three themes and provides guidance on potential research trajectories which would fulfill the gaps in this literature (the items are listed in Table 3).

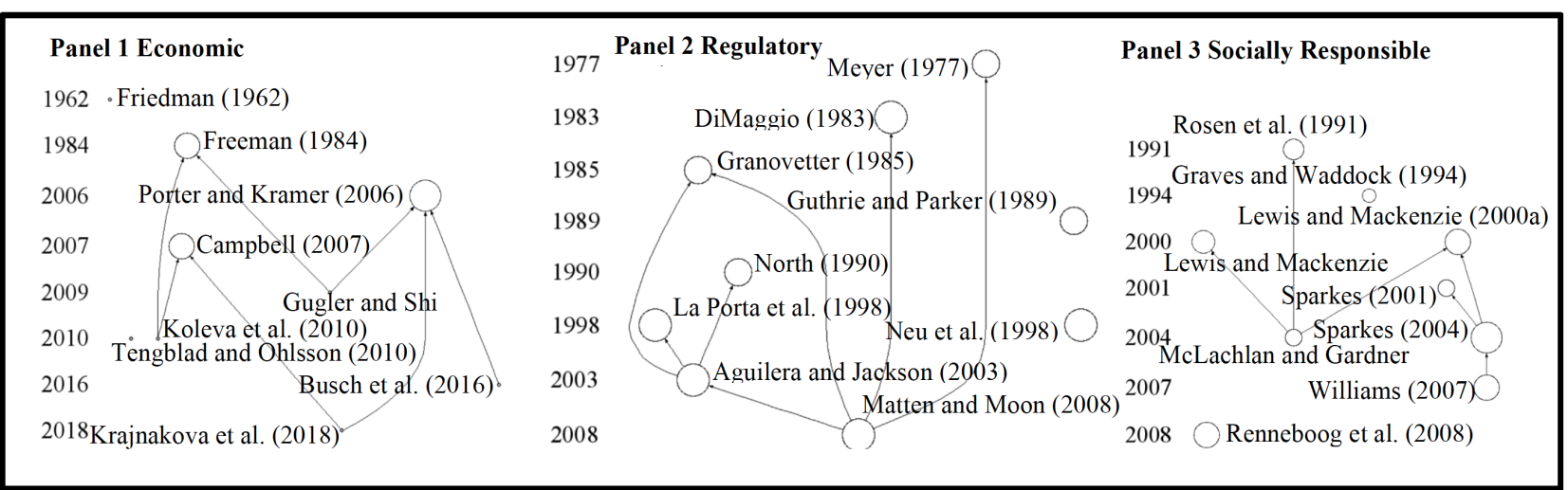

Figure 5. Mini citation graphs. This figure is generated by HistCite to show the smaller citation clusters associated with the three themes, i.e., economic drivers, regulatory impact and the influence of socially responsible investors. Each item is represented by a circle. The size of the circles indicates the number of times the item is cited throughout the collection. The items are plotted according to time, i.e., earlier publications are located at the top of the graph and recent articles at the bottom. Lines between items identify their citations to each other. 
Table 3. References in mini citation graphs.

\begin{tabular}{|c|c|c|}
\hline Collection \# & Reference & LCS \\
\hline & Panel 1 Economic Development & \\
\hline 1 & Friedman [43] "Capitalism and freedom" & 0 \\
\hline 2 & Freeman [4] "Strategic management: A stakeholder approach" & 2 \\
\hline 3 & Porter [32] "The link between competitive advantage and corporate social responsibility" & 3 \\
\hline 4 & $\begin{array}{l}\text { Campbell [26] "Why would corporations behave in socially responsible ways? An institutional theory of } \\
\text { corporate social responsibility" }\end{array}$ & 2 \\
\hline 5 & $\begin{array}{l}\text { Gugler [63] "Corporate Social Responsibility for Developing Country Multinational Corporations: Lost War } \\
\text { in Pertaining Global Competitiveness?" }\end{array}$ & 0 \\
\hline 6 & $\begin{array}{l}\text { Tengblad [64] "The Framing of Corporate Social Responsibility and the Globalization of National Business } \\
\text { Systems: A Longitudinal Case Study" }\end{array}$ & 0 \\
\hline 7 & $\begin{array}{l}\text { Koleva [65] "Is corporate social responsibility the privilege of developed market economies? Some evidence } \\
\text { from Central and Eastern Europe" }\end{array}$ & 0 \\
\hline 8 & Busch [66] "Sustainable Development and Financial Markets: Old Paths and New Avenues" & 0 \\
\hline \multirow[t]{2}{*}{9} & $\begin{array}{l}\text { Krajnakova [67] "Effect of macroeconomic business environment on the development of corporate social } \\
\text { responsibility in Baltic Countries and Slovakia" }\end{array}$ & 0 \\
\hline & Panel 2 Regulatory Environment & \\
\hline 1 & Meyer [68] "The effects of education as an institution" & 3 \\
\hline 2 & $\begin{array}{l}\text { DiMaggio [28] "The iron cage revisited: Institutional isomorphism and collective rationality in organizational } \\
\text { fields" }\end{array}$ & 4 \\
\hline 3 & Granovetter [69] "Economic action and social structure: The problem of embeddedness" & 3 \\
\hline 4 & Guthrie [70] "Corporate social reporting: A rebuttal of legitimacy theory" & 3 \\
\hline 5 & North [71] "Institutions, institutional change and economic performance" & 3 \\
\hline 6 & Neu [72] "Managing public impressions: Environmental disclosures in annual reports" & 4 \\
\hline 7 & LaPorta [73] "Law and finance" & 4 \\
\hline 8 & Aguilera [74] "The cross-national diversity of corporate governance: Dimensions and determinants" & 4 \\
\hline 9 & $\begin{array}{l}\text { Matten [55] "'Implicit' and 'explicit' CSR: A conceptual framework for a comparative understanding of } \\
\text { corporate social responsibility" }\end{array}$ & 4 \\
\hline
\end{tabular}

Panel 3 Socially Responsible Investing

1 Rosen [75] "Social issues and socially responsible investment behavior: A preliminary empirical investigation"

2 Graves [45] "Institutional owners and corporate social performance" 2

3 Lewis [76] "Morals, money, ethical investing and economic psychology" 6

$4 \quad$ Lewis [77] "Support for investor activism among UK ethical investors" 5

$5 \quad$ Sparkes [78] "Ethical investment: Whose ethics, which investment?" 3

6 Sparkes [54] "The maturing of socially responsible investment: A review of the developing link with 9 corporate social responsibility"

$7 \quad$ McLachlan [79] "A comparison of socially responsible and conventional investors" 3

8 Williams [80] “Some Determinants of the Socially Responsible Investment Decision A Cross Country Study" 6

9 Renneboog [81] "Socially responsible investments: Institutional aspects, performance, and investor behavior"

This table lists the references displayed in the mini citation graphs displayed in Figure 5. Collection number is the number of the article in each mini collection in order of publication date. The reference details show the authors, year of publication and article title. LCS is the local citation score within the mini collection. 
Panel 1. Economic Development While Tengblad [64] document growing societal expectations for corporate responsibility, there is a dearth of articles which address the influence of the economic development on ESG outcomes. From the few which address the economic development, Panel A shows the most cited articles are drawn from the management articles which dominate the complete collection: Freeman [4], Porter [32] and Campbell [26]. Freeman [4] presents "an integrative view of morality and strategic decision making" ([82], p. 67). Porter [32] add competitive advantage to create the business case for responsible practice. Relative competitive advantage is then employed by Gugler [63] to explain the gaps which exist between developed and developing countries. They argue that the gap can be reduced through policy participation by both categories and by defining obligations in international law. Koleva [65] investigate the development gap in relation to Baltic countries. They suggest there is less of a gap once we recognise changes that responsibility practices undergo when introduced to individual countries, especially in light of past culture.

The other major cited work, Campbell [26], builds on the relationship between economic conditions and responsible behaviour. He finds that the relationship is positively mediated by the presence of nongovernment and other independent organisations monitoring direct and associative behaviour, behavioural norms and organised dialogue between corporations and their stakeholders. Busch [66] study the potential for developed financial markets to also contribute a facilitating. However, they conclude that financial markets have only provided a modest contribution and two major obstacles persist: a reorientation to longer-term paradigms of sustainable investment and more trustworthy ESG data. However, Krajnakova [67] contribute some evidence that a reorientation to longer-term perspectives is occurring. Their main focus was on how fluctuating economic activity created diverse impacts on dimensions of CSR. However, they were able to discern continuing development of socially responsible businesses through unfavourable macroeconomic conditions (in Baltic countries) attributable to long run benefits.

In addition to major elements of economic development not currently addressed in the literature, there is also a significant scope to expand the global coverage of this topic area. The literature on economic influence has largely focused on individual countries of tightly defined regions. The focus has been on Sweden [64], the Central and Eastern European countries [65] and the Baltic countries [67]. There is considerable scope to expand the analysis of how economic development impacts ESG performance in more countries and regions.

Panel 2. Regulatory Environment LaPorta [73] survey the strength of investor protection across 49 countries. These authors show that the countries with common-law origins have the strongest protections and French civil law the weakest. This feature is important for understanding the impact by investors on company behaviour. Investors with strongly protected rights will potentially have greater influence. Matten [55] extend this dimension of awareness by specifically analysing why some countries have different levels of reasonability. The new framework they provide distinguishes "implicit" and "explicit" responsibility and will likely facilitate identifying specific regulatory improvements in the future.

DiMaggio [28] also present an innovative framework to comprehend the forces which cause organisational change. This framework provides a lens by which we can understand how regulation can fit (as a coercive force) alongside less formal influences. Another new model to understand cross national diversity to responsibility is the "actor-centred" institutional approach of Aguilera [83]. This granularly designed firm-level has important potential to boost international convergence.

Panel 3. Socially Responsible Investing The over-riding objective of this article is to understand what drives ESG performance. In relation to investors, the question becomes, do investors drive ESG performance? If so, how do they and what would attract more investors and more impact? The literature that meets this area is again fairly sparse (e.g., only 28 articles from the major collection plus a further 3 articles cited by these 28 articles). 
Of the most highly cited nine articles on investors, there are two natural groups: retail investors and institutional investors.

The retail focused articles herald the engagement by individuals with socially responsible investing. They document trends and identify characteristics of retail SRI investors. These individuals are younger and better educated than conventional investors [75]. This suggests an opportunity to engage individuals (where SRI is not yet prevalent) by including relevant curriculum in a country's tertiary education [84]. McLachlan [79] dispute the observation that responsible investors are younger and more educated. These authors offer an alternative, more nuanced understanding of the individual responsible investor. They argue the differences relate to decision-making style, perceptions of moral intensity and beliefs on ethical issues. Their findings imply more complicated strategies are necessary to engage individuals in SRI. Relevant strategies include interventions and behavioural nudges in decision-making approaches and cultural shifts on attitudes towards ethics and the consequences of our actions.

Despite this cluster of articles still in a stage of development, there are some initial lessons and future pathways to support retail investors' efforts to improve corporate behaviour. The main lesson is that investors can be effective through active engagement [77] and shareholder action [78]. Further, these articles present innovations and new applications for theory which can expand the strategies available to investors. The extensions presented are mainly around recognising the difference between rational investor and SRI investors [79]. They therefore involve extending to a more "economic psychology" approach [77] and using the utility from these stakeholder models to justifying investor actions [78].

The literature on institutional SRI documents the maturing of this industry and its adoption of SRI as an integral element of its philosophies [54]. Consistent with retail investors, active engagement has proven a successful strategy. This literature also presents evidence to motivate good corporate behaviour. Graves [45] show that responsible behaviour attracts more institutional investors. This small collection also contains directions for fruitful future research across corporate finance, asset pricing and financial intermediation [81].

\section{Conclusions and Future Research Agenda}

There is a significant difference in levels and trends of ESG performance observed across the world. However, a global alignment of successful ESG outcomes is required to meet the challenges facing the world. This need motivates a thorough collation of the actions required to drive positive ESG outcomes. Given that the literature on what drives ESG performance is highly fragmented and current theories fail to offer useful insights into the disparity in ESG performance, the purpose of this article is to organise an accumulated body of knowledge of ESG-related literature and explore the major drivers of ESG performance. The findings will facilitate better selection and implementation of policies by governments, more impactful strategies by investment managers and more effective ESG practices by corporate management.

The published work on the drivers of ESG performance provides direction on what levers will harness better performance. Early influential writing raised the spectre that market freedom should be the central prerogative of business management and that government should present little interference [43]. However, in its purest form, this implies a country could either prioritise social outcomes or a profitable economy but not both. We could therefore expect to see an inverse relationship between economic success and social scores. There is some evidence that this pattern currently exists across the globe and poses the worrying proposition that some governments and regulators follow this dictum. In contrast, the vast bulk of the relevant literature collection holds the view that business should be responsible for a wider set of responsibilities.

The most highly cited of the literature relevant to what drives ESG performance creates four categories. These categories illuminate our understanding of the landscape of the relevant literature. The first category focuses on the key debate: laissez-faire business activity 
vs. ESG responsibilities. The articles in this category set out the issue which underpins much of the literature plus an archetypal model for understanding the issues. The second area demonstrates the potential heterogeneous nature of the actors relevant to this body of knowledge. It is a collection of research showing distinctly difference perspectives, e.g., employees, customers, institutional investors, etc. The third area emphasises stakeholder theory, including the importance of where the line between stakeholders and the wider community should be drawn. The fourth area provides an overview of the innovative theories and frameworks being developed to understand, monitor and manage business' social responsibilities. These innovative frameworks are worth focusing on because they contain structures which will inform future empirical research and evaluate the alternative levers to achieve positive ESG outcomes.

Business responsibility for societal concerns is the focus of frameworks incorporating institutional, organisational and individual perspectives [44,62]. Business has societal responsibilities because it has economic power. Business is responsible for fixing issues associated with its society impacting activities. Further, the individuals managing businesses have moral codes which motivate business responsibilities. This framework can be applied to specific firm and country conditions which affect ESG performance. For example, business would be expected to have stronger ESG performance where companies operate in an oligopolistic environment, have significant impact on society and where a country's culture imposes high moral codes of conduct. Classifying the drivers into institutional, organisational and individual levels helps clarify the conditions which regulators should support.

The institutional isomorphic framework provides a detailed assessment of the three major mechanisms to achieve ESG outcomes [28]. Coercive isomorphism can be achieved through political policy and society's demands for legitimacy. Mimetic isomorphism can operate if ESG supportive strategies become the standard response to risk across an industry, market or country. Normative isomorphism can be achieved through industry recognition of the CSR, ESG and SRI professions. This framework therefore presents the market infrastructure and societal behaviour which will best support ESG performance.

Stakeholder theory also provides a precise understanding of which particular ESG outcomes are likely to be delivered by business and which will require other actors (e.g., government, charities, intergovernmental organisations, etc.). The stakeholders of a business are identified through their relationship to the business. Mitchell [49] provide criteria to identify the business stakeholders with reference to power, legitimacy and urgency. These criteria imply detailed information about the composition of a country's societal needs is necessary in order to assess the appropriate mix of pro-business policies and social welfare policies.

Throughout the collection of literature relevant to what drives ESG, there is a predominant focus on corporate management and strategy. A thorough review of the full collection of relevant literature reveals ground-breaking themes on economic drivers, regulatory impact and the influence of socially responsible investors. However, examining these emergent themes raises potential limitations in the analysis. The nature of citation network mapping requires the researchers to choose a minimum citation threshold to include publications into the citation network which can create issues for visualising literature reviews if the number of papers to be included is too large. Hence, our research is limited by its focus on major published work and did not include preliminary research discussions such as working papers and conference presentations. Given that one of our goals is to visualise topic development on ESG drivers over time, this approach remains appropriate.

Overall, this article contributes to the literature by detailing the aspects of these themes covered to date and the potential future trajectories requiring further development. This future research will inform all the important actors who have potential to contribute to improving ESG outcomes and thereby transforming the globe. Given that many papers in the citation map focus on advanced economies, future research may also look into key drivers that limit ESG investing capacity in emerging and frontier market countries, which 
face considerable challenges, including poverty and pollution, at the same time. A close examination in an international context could help achieve the sustainable development goals on a global scale.

Author Contributions: Conceptualisation, D.D. and A.D.; methodology, D.D. and A.D.; software, D.D. and A.D.; validation, D.D. and A.D.; formal analysis, D.D. and A.D.; investigation, D.D. and A.D.; resources, D.D. and A.D.; data curation, D.D. and A.D.; writing-original draft preparation, D.D. and A.D.; writing-review and editing, D.D. and A.D.; visualisation, D.D. and A.D.; supervision, D.D.; project administration, A.D. All authors have read and agreed to the published version of the manuscript.

Funding: This research received no external funding.

Institutional Review Board Statement: Not applicable.

Informed Consent Statement: Not applicable.

Data Availability Statement: We have sourced citation data from the Web of Science and provided the details within the text of the article on how to replicate this set of citation from their database.

Acknowledgments: The authors are grateful for the insightful observations contributed by Martina Linnenluecke and for the constructive suggestions from our colleagues attending the Applied Finance Department seminar series at Macquarie Business School, 2020. The authors also thank the anonymous reviewers for their careful reading of the manuscript and their many insightful comments and suggestions.

Conflicts of Interest: The authors declare no conflict of interest.

\section{References}

1. IPCC. Global Warming of $1.5^{\circ} \mathrm{C}$ : An IPCC SPECIAL Report on the Impacts of Global Warming of $1.5^{\circ} \mathrm{C}$ above Pre-Industrial Levels and Related Global Greenhouse Gas Emission Pathways, in the Context of Strengthening the Global Response to the Threat of Climate Change; 2018. Available online: https:/ / www.ipcc.ch/sr15/ (accessed on 18 January 2022).

2. George, G.; Howard-Grenville, J.; Joshi, A.; Tihanyi, L. Understanding and tackling societal grand challenges through management research. Acad. Manag. J. 2016, 59, 1880-1895. [CrossRef]

3. Jensen, M.C.; Meckling, W.H. Theory of the firm: Managerial behavior, agency costs and ownership structure. J. Financ. Econ. 2016, 3, 305-360. [CrossRef]

4. Freeman, R. Strategic Management: A Stakeholder Approach; Pitman: Boston, MA, USA, 1984.

5. Michelon, G.; Parbonetti, A. The effect of corporate governance on sustainability disclosure. J. Manag. Gov. 2012, 16, 477-509. [CrossRef]

6. Brammer, S.; Millington, A. Corporate reputation and philanthropy: An empirical analysis. J. Bus. Ethics 2005, 61, 29-44. [CrossRef]

7. Dhaliwal, D.S.; Radhakrishnan, S.; Tsang, A.; Yang, Y.G. Nonfinancial disclosure and analyst forecast accuracy: International evidence on corporate social responsibility disclosure. Account. Rev. 2012, 87, 723-759. [CrossRef]

8. Porter, M.E.; Kramer, M.R. The Competitive Advantage of Corporate Philanthropy. Harv. Bus. Rev. 2002, 80, 56-133.

9. Linnenluecke, M.K.; Chen, X.; Ling, X.; Smith, T.; Zhu, Y. Research in Finance: A Review of Influential Publications and a Research Agenda. Pac.-Basin Financ. J. 2017, 43, 188-199. [CrossRef]

10. Janssen, M.A. An update on the scholarly networks on resilience, vulnerability, and adaption within the human dimensions of global environmental change. Ecol. Soc. 2007, 12, 9-27. [CrossRef]

11. Janssen, M.A.; Schoon, M.L.; Ke, W.; Börner, K. Scholarly networks on resilience, vulnerability and adaptation within the human dimensions of global environmental change. Glob. Environ. Chang. 2006, 16, 240-252. [CrossRef]

12. O'Brien, R. Global Financial Integration: The End of Geography; Royal Institute of International Affairs: London, UK, 1992.

13. ESG Ratings. Available online: https://www.sustainalytics.com/esg-ratings (accessed on 1 January 2022).

14. Fiksel, J. Sustainability and resilience: Toward a systems approach. Sustain. Sci. Pract. Policy 2006, 2, 14-21. [CrossRef]

15. European and U.S. Asset Owners' Approaches to ESG: What Investment Managers Need to Know. Available online: https://www. issgovernance.com/file/publications/european-and-u.s.-asset-owners-approaches-to-esg.pdf (accessed on 1 January 2022).

16. The ESG Risk Atlas: Sector and Regional Rationales and Scores. S\&P Global Ratings. Available online: https://www.spglobal. com/_media/documents/ratingsdirect_theesgriskatlassectorandregionalrationalesandscores_41534468_may-15-2019.pdf (accessed on 1 January 2022).

17. Drempetic, S.; Klein, C.; Zwergel, B. The Influence of Firm Size on the ESG Score: Corporate Sustainability Ratings Under Review. J. Bus. Ethics 2020, 167, 333-360. [CrossRef]

18. Del Giudice, A.; Rigamonti, S. Does audit improve the quality of ESG scores? Evidence from corporate misconduct. Sustainability 2020, 12, 5670. [CrossRef] 
19. Galbreath, J. ESG in Focus: The Australian Evidence. J. Bus. Ethics 2013, 118, 529-541. [CrossRef]

20. Birindelli, G.; Dell'Atti, S.; Iannuzzi, A.P.; Savioli, M. Composition and activity of the board of directors: Impact on ESG performance in the banking system. Sustainability 2018, 10, 4699. [CrossRef]

21. Bizoumi, T.; Lazaridis, S.; Stamou, N. Innovation in stock exchanges: Driving ESG disclosure and performance. J. Appl. Corp. Financ. 2019, 31, 72-79. [CrossRef]

22. Innis, S.; Kunz, N.C. The role of institutional mining investors in driving responsible tailings management. Extr. Ind. Soc. 2020, 7, 1377-1384. [CrossRef]

23. Kölbel, J.F.; Heeb, F.; Paetzold, F.; Busch, T. Can sustainable investing save the world? Reviewing the mechanisms of investor impact. Organ. Environ. 2020, 33, 554-574. [CrossRef]

24. Garcia, A.S.; Mendes-Da-Silva, W.; Orsato, R. Sensitive industries produce better ESG performance: Evidence from emerging markets. J. Clean. Prod. 2017, 150, 135-147. [CrossRef]

25. Nejati, M.; Salamzadeh, Y.; Loke, C.K. Can ethical leaders drive employees' CSR engagement? Soc. Responsib. J. 2020, 16, 655-669. [CrossRef]

26. Campbell, J.L. Why would corporations behave in socially responsible ways? An institutional theory of corporate social responsibility. Acad. Manag. Rev. 2007, 32, 946-967. [CrossRef]

27. Zyglidopoulos, S.C.; Georgiadis, A.P.; Carroll, C.E.; Siegel, D.S. Does media attention drive corporate social responsibility? J. Bus. Res. 2012, 65, 1622-1627. [CrossRef]

28. DiMaggio, P.J.; Powell, W.W. The Iron Cage Revisited: Institutional Isomorphism and Collective Rationality in Organizational Fields. Am. Sociol. Rev. 1983, 48, 147-160. [CrossRef]

29. Carroll, A.B. A three-dimensional conceptual model of corporate performance. Acad. Manag. Rev. 1979, 4, 497-505. [CrossRef]

30. Carroll, A.B. The pyramid of corporate social responsibility: Toward the moral management of organizational stakeholders. Bus. Horiz. 1991, 34, 39-48. [CrossRef]

31. Mirvis, P. Unilever's Drive for Sustainability and CSR—Changing the Game. In Organizing for Sustainability; Emerald Group Publishing Ltd.: Bentley, UK, 2011; pp. 41-72.

32. Porter, M.E.; Kramer, M.R. The link between competitive advantage and corporate social responsibility. Harv. Bus. Rev. 2006, 84, 78-92. [PubMed]

33. Waddock, S.A.; Graves, S.B. The corporate social performance-financial performance link. Strateg. Manag. J. 1997, 18, 303-319. [CrossRef]

34. Vashchenko, M. An external perspective on CSR: What matters and what does not? Bus. Ethics Eur. Rev. 2017, 26, 396-412. [CrossRef]

35. Ali, W.; Frynas, J.G.; Mahmood, Z. Determinants of corporate social responsibility (CSR) disclosure in developed and developing countries: A literature review. Corp. Soc. Responsib. Environ. Manag. 2017, 24, 273-294. [CrossRef]

36. Linnenluecke, M.K.; Griffiths, A. Firms and sustainability: Mapping the intellectual origins and structure of the corporate sustainability field. Glob. Environ. Chang. 2013, 23, 382-391. [CrossRef]

37. Garfield, E. Historiographic mapping of knowledge domains literature. J. Inf. Sci. 2004, 30, 119-145. [CrossRef]

38. Garfield, E. From the science of science to Scientometrics visualizing the history of science with HistCite software. J. Inf. 2009, 3, 173-179. [CrossRef]

39. Capelle-Blancard, G.; Monjon, S. Trends in the literature on socially responsible investment: Looking for the keys under the lamppost. Bus. Ethics Eur. Rev. 2012, 21, 239-250. [CrossRef]

40. Sandberg, J.; Juravle, C.; Hedesstrom, T.M.; Hamilton, I. The heterogeneity of socially responsible investment. J. Bus. Ethics 2009, 87, 519-533. [CrossRef]

41. Friedman, M. The social responsibility of business is to increase its profits. New York Times Magazine, 1970, pp. 122-126. Available online: https:/ / www.nytimes.com/1970/09/13/archives/a-friedman-doctrine-the-social-responsibility-of-business-is-to.html (accessed on 18 January 2022).

42. Bowen, H.R. Social Responsibility of the Businessman; University of Iowa Press: Iowa City, IA, USA, 1953.

43. Friedman, M. Capitalism and Freedom; University of Chicago Press: Chicago, IL, USA, 1962.

44. Wood, D. Corporate social performance revisited. Acad. Manag. Rev. 1991, 16, 691-718. [CrossRef]

45. Graves, S.B.; Waddock, S.A. Institutional owners and corporate social performance. Acad. Manag. J. 1994, 37, 1034-1104.

46. Donaldson, T.; Preston, L.E. The stakeholder theory of the corporation: Concepts, evidence, and implications. Acad. Manag. Rev. 1995, 20, 65-91. [CrossRef]

47. Clarkson, M.E. A stakeholder framework for analyzing and evaluating corporate social performance. Acad. Manag. Rev. 1995, 20, 92-117. [CrossRef]

48. Turban, D.B.; Greening, D.W. Corporate social performance and organizational attractiveness to prospective employees. Acad. Manag. J. 1997, 40, 658-672.

49. Mitchell, R.K.; Agle, B.R.; Wood, D.J. Toward a theory of stakeholder identification and salience: Defining the principle of who and what really counts. Acad. Manag. Rev. 1997, 22, 853-886. [CrossRef]

50. Carroll, A.B. Corporate social responsibility: Evolution of a definitional construct. Bus. Soc. 1999, 38, 269-295. [CrossRef]

51. McWilliams, A.; Siegel, D. Corporate social responsibility: A theory of the firm perspective. Acad. Manag. Rev. 2001, 26, 117-127. [CrossRef] 
52. Sen, S.; Bhattacharya, C.B.A. Does doing good always lead to doing better? Consumer reactions to corporate social responsibility. J. Mark. Res. 2001, 38, 225-243. [CrossRef]

53. Margolis, J.D.; Walsh, J.P. Misery Loves Companies: Rethinking Social Initiatives by Business. Adm. Sci. Q. 2003, 48, $268-305$.

54. Sparkes, R.; Cowton, C.J. The maturing of socially responsible investment: A review of the developing link with corporate social responsibility. J. Bus. Ethics 2004, 52, 45-57. [CrossRef]

55. Matten, D.; Moon, J. "Implicit" and "explicit" CSR: A conceptual framework for a comparative understanding of corporate social responsibility. Acad. Manag. Rev. 2008, 33, 404-424. [CrossRef]

56. Acquier, A.; Gond, J.P.; Pasquero, J. Rediscovering Howard R. Bowen's legacy: The unachieved agenda and continuing relevance of social responsibilities of the businessman. Bus. Soc. 2011, 50, 607-646. [CrossRef]

57. Edmans, A. Company purpose and profit need not be in conflict if we "grow the pie". Econ. Aff. 2020, 40, 287-294. [CrossRef]

58. Torugsa, N.A.; O'Donohue, W.; Hecker, R. Proactive CSR: An Empirical Analysis of the Role of its Economic, Social and Environmental Dimensions on the Association between Capabilities and Performance. J. Bus. Ethics 2013, 115, 287-294. [CrossRef]

59. Pedrini, M.; Ferri, L.M. Stakeholder management: A systematic literature review. Corp. Gov. Int. J. Bus. Soc. 2019, 19, 44-59. [CrossRef]

60. Jones, T.M. Instrumental stakeholder theory: A synthesis of ethics and economics. Acad. Manag. Rev. 1995, 20, 404-437. [CrossRef]

61. Hillman, A.J.; Keim, G.D. Shareholder value, stakeholder management, and social issues: What's the bottom line? Strateg. Manag. J. 2001, 22, 125-139. [CrossRef]

62. Aguinis, H.; Glavas, A. What we know and don't know about corporate social responsibility: A review and research agenda. J. Manag. 2012, 38, 932-968. [CrossRef]

63. Gugler, P.; Shi, J.Y.J. Corporate Social Responsibility for Developing Country Multinational Corporations: Lost War in Pertaining Global Competitiveness? J. Bus. Ethics 2009, 87, 3-24. [CrossRef]

64. Tengblad, S.; Ohlsson, C. The Framing of Corporate Social Responsibility and the Globalization of National Business Systems: A Longitudinal Case Study. J. Bus. Ethics 2010, 93, 653-669. [CrossRef]

65. Koleva, P.; Rodet-Kroichvili, N.; David, P.; Marasova, J. Is corporate social responsibility the privilege of developed market economies? Some evidence from Central and Eastern Europe. Int. J. Hum. Resour. Manag. 2009, 21, 274-293. [CrossRef]

66. Busch, T.; Bauer, R.; Orlitzky, M. Sustainable Development and Financial Markets: Old Paths and New Avenues. Bus. Soc. 2016, 8, 43-57. [CrossRef]

67. Krajnakova, E.; Navickas, V.; Kontautiene, R. Effect of macroeconomic business environment on the development of corporate social responsibility in Baltic Countries and Slovakia. Oeconomia Copernic. 2018, 9, 477-492. [CrossRef]

68. Meyer, J.W. The effects of education as an institution. Am. J. Sociol. 1977, 83, 55-77. [CrossRef]

69. Granovetter, M. Economic action and social structure: The problem of embeddedness. Am. J. Sociol. 1985, 91, 481-510. [CrossRef]

70. Guthrie, J.; Parker, L.D. Corporate social reporting: A rebuttal of legitimacy theory. Account. Bus. Res. 1989, 19, 343-352. [CrossRef]

71. North, D.C. Institutions, Institutional Change and Economic Performance; Cambridge University Press: Cambridge, UK, 1990.

72. Neu, D.; Warsame, H.; Pedwell, K. Managing public impressions: Environmental disclosures in annual reports. Account. Organ. Soc. 1988, 23, 265-282. [CrossRef]

73. La Porta, R.; Lopez-de-Silanes, F.; Shleifer, A.; Vishny, R.W. Law and Finance. J. Political Econ. 1998, 106, 1113-1155. [CrossRef]

74. Aguilera, R.V.; Jackson, G. The cross-national diversity of corporate governance: Dimensions and determinants. Acad. Manag. Rev. 2003, 28, 447-465. [CrossRef]

75. Rosen, B.N.; Sandler, D.M.; Shani, D. Social Issues and Socially Responsible Investment Behavior: A Preliminary Empirical Investigation. J. Consum. Aff. 1991, 25, 221-234. [CrossRef]

76. Lewis, A.; Mackenzie, C. Morals, money, ethical investing and economic psychology. Hum. Relat. 2000, 53, 179-191. [CrossRef]

77. Lewis, A.; Mackenzie, C. Support for investor activism among UK ethical investors. J. Bus. Ethics 2000, 24, 215-222. [CrossRef]

78. Sparkes, R. Ethical investment: Whose ethics, which investment? Bus. Ethics Eur. Rev. 2001, 10, 194-205. [CrossRef]

79. McLachlan, J.; Gardner, J. A comparison of socially responsible and conventional investors. J. Bus. Ethics 2004, 52, 11-25. [CrossRef]

80. Lewis, A.; Mackenzie, C. Some Determinants of the Socially Responsible Investment Decision A Cross Country Study. J. Behav. Financ. 2007, 8, 43-57.

81. Renneboog, L.; Ter Horst, J.; Zhang, C.D. Socially responsible investments: Institutional aspects, performance, and investor behavior. J. Bank. Financ. 2008, 32, 1723-1742. [CrossRef]

82. Minoja, M. Stakeholder management theory, firm strategy, and ambidexterity. J. Bus. Ethics 2012, 109, 67-82. [CrossRef]

83. Aguilera, R.V.; Rupp, D.E.; Williams, C.A.; Ganapathi, J. Putting the S back in corporate social responsibility: A multilevel theory of social change in organizations. Acad. Manag. Rev. 2007, 32, 836-863. [CrossRef]

84. Belinga, R.; Morsing, M. Teaching Sustainable Finance. Available online: https://www.hhs.se/contentassets/0442e753dd9e45f6 b3e0aa79c24b1126/teaching-sustainable-finance-2020_misum_rachelle-belinga_final2.pdf (accessed on 1 January 2022). 